\title{
KRZYSZTOF MICHALCZAK Posługi świeckich wiernych w życiu Kościoła
}

Zagadnienie posługi świeckich wiernych w życiu Kościoła jest przedmiotem żywej dyskusji, zwłaszcza w Kościołach lokalnych na Zachodzie. Problem ten powoli zaczyna się pojawiać także w Polsce, głównie w prowadzonych debatach, m.in. na łamach czasopism. Ostatnio taka dyskusję wywoła publikacja nt. ministrantek, ogłoszona na łamach „Tygodnika Powszechnego"1. Wydaje się zatem słuszne, aby włączyć się do tej dyskusji poprzez refleksję nad kształtem Kościoła w XXI w. i posługą świeckich wiernych w ramach kościelnej wspólnoty.

Punktem wyjścia wszelkiej refleksji na ten temat jest przypomnienie, iż w Kościele istnieja różne stany życia, z których wynika różnorodność posług ministeriów. Nie można mówić o specyficznym powolaniu świeckich wiernych, o ich posługach, bez odwołania się do teologii i istoty kaplaństwa chrześcijańskiego, zarówno ministerialnego jak powszechnego, wynikającego z chrztu i bierzmowania.

Św. Tomasz z Akwinu, ukazując relację między Kościołem i funkcją kapłańską, nawiązywał do Pisma św. Mówił najpierw o jedynym kapłaństwie Chrystusa, potem o powszechnym kaplaństwie wiernych, a na koniec o kapłaństwie urzędowym, dzisiaj nazywanym ministerialnym² ${ }^{2}$.

${ }^{1}$ Zob. E. Adamiak: Dziewczyny przy oftarzu. „Tygodnik Powszechny”. R. 2003 nr 40 s. 10 (zob. także - J. Prusak: Ministrantki kontra klerykalizm. Kobieta w „męskim” Kościele. „Tygodnik Powszechny". R. 2003 nr 42 s. 11, a także opublikowane w nim listy czytelników).

${ }^{2}$ Por. K. Michalczak: Świeccy i kapłaństwo. Wokót poszukiwań teologicznych Y. Congara. Poznań 2001 s. 53-64. Uniwersytet im. Adama Mickiewicza. Wydział Teologiczny. Seria: 
Pod koniec XIX w. i w XX w. dokonal się powrót do źródeł Kościoła, przede wszystkim dzięki odnowie biblijnej i liturgicznej. Odczytane na nowo Pismo Święte ukazalo, że już w Starym Testamencie wiele się mówilo na temat kapłaństwa. Cały lud przedstawiano tam jako kaplański, a w nim dopiero widziano istnienie kapłaństwa funkcyjnego. Nowy Testament zaś to już wielka księga o kaplaństwie. List do Hebrajczyków, ale także listy św. Piotra i św. Pawla oraz Apokalipsa świadczą, że istnieje tylko jeden kapłan - Jezus Chrystus; dalej, że wszyscy uczestniczą w funkcji kapłańskiej, prorockiej i królewskiej Jezusa Chrystusa; wreszcie, że niektórzy sprawują kapłaństwo urzędowe ${ }^{3}$.

To, co przenikało Kościół dzięki odnowie biblijnej i liturgicznej, znajdowało swoje miejsce $w$ orzeczeniach magisterium Kościoła poczynając od papieża Leona XIII, przez okres pontyfikatu Piusa XI i Piusa XII, skończywszy na dekretach Soboru Watykańskiego II.

Spróbujmy zatem pochylić się nad teologią Kościoła i kapłaństwa. Nie można bowiem mówić o posłudze świeckich wiernych bez całościowego spojrzenia na to, czym jest Kościół oraz jakie każdy ma w nim obowiązki i prawa.

\section{Kapłaństwo Chrystusa źródłem naszego kapłaństwa}

Kościól jest wspólnotą ludzi ochrzczonych. Tak więc przez chrzest i bierzmowanie jesteśmy wszczepieni w Chrystusa. Stąd nasza godność i równość. Dlatego zanim mówimy o kapłaństwie nam przynależnym, musimy zatrzymać się na osobie Jezusa Chrystusa - jedynego i Najwyższego Kapłana. Jest to konieczne, aby dobrze zrozumieć nasze zadania we wspólnocie Kościola, odkryć cel naszego zaangażowania ${ }^{4}$. Najpierw trzeba zobaczyć Źródło kapłaństwa. Jest nim Jezus Chrystus, jedyny i najwyższy Kapłan. Kapłaństwo bowiem jest nierozerwalnie zwiazzane $z$ ofiara (sacerdos et hostia). Jedyną, najwyższą i niepowtarzalną ofiarę złożył Jezus Chrystus. Dzięki temu jest On jedynym Kapłanem i Ofiarą Nowego Przymierza. Stało się tak dzięki wcieleniu. Chrystus jest Pośrednikiem między nami a Bogiem dzięki temu, że przyjął ludzkie ciało. W akcie odkupienia istotna jest więc nie tylko boska natura Chrystusa, ale także ludzka.

Materialy i Studia - 42 (zob. także: A. Zuberbier: Kapłaństwo Nowego Przymierza. „Znak”. R. 49: $1997 \mathrm{nr} 11(510)$ s. 4-17.

${ }^{3}$ Por. K. Michalczak, dz. cyt., s. $18-38$.

${ }^{4}$ Por. S. Rylko: La vocation et la mission des laïcs à la lumière du magistère ecclésia, W: Laïcs aujourd'hui, $1^{\text {er }}$ Congrès des laïcs catholiques du Moyen - Orien. Cité du Vatican $1998 \mathrm{~s}$. $32-39$. 
Kaplaństwo Chrystusa jest więc źródłem naszego kaplaństwa powszechnego, które wynika z chrztu i bierzmowania. Ono też jest źródłem kapłaństwa ministerialnego (sakramentalnego). Ontologicznie rzecz biorąc, wszyscy wierni ochrzczeni sa wspólnotą, w której każdy ma do spelnienia we wspólnocie swoje, niepowtarzalne zadanie. Jest zasadnicza równość wszystkich w godności kaplańskiej. Nie ma więc różnicy od strony ontologicznej. Jest zaś zróżnicowanie posług w służbie Kościoła.

\section{Kościół wspólnotą wszystkich ochrzczonych}

Trudno dzisiaj zgodzić się z usiłowaniem przedstawienia wspólnoty Kościola w kształcie piramidy, na czele której jest Chrystus jako Alfa i Omega, Głowa i Pan Kościoła, następnie kapłani z biskupami na czele, wreszcie na samym dole poddani ich pieczy świeccy. Kościół bowiem to społeczność wszystkich ochrzczonych, przedstawiana jako wspólnota, nad którą jest Jezus Chrystus. Schemat ten lepiej pokazuje, że kapłani, sprawując specyficzną funkcję, pozostaja członkami wspólnoty. Sa jednocześnie szafarzami wspólnoty i dla wspólnoty. Schemat ten nawiazuje do twierdzenia św. Augustyna, który powiedzial: Dla was jestem biskupem, $z$ wami jestem chrześcijaninem ${ }^{5}$.

Rzeczywistość apostolstwa jest udziałem całego Kościoła, gdyż, jak uznaje soborowa Konstytucja Dei verbum: cały lud święty zjednoczony ze swymi pasterzami trwa stale w nauce Apostołów, we wspólnocie braterskiej, w łamaniu chleba $i$ w modlitwach (por. Dz 2, 42 gr.), tak iż zaznacza się jednomyślność przełozonych $i$ wiernych $w$ zachowywaniu przekazanej wiary, w praktykowaniu jej $i$ wyznawaniu $^{6}$. Tekst ten wyraźnie mówi, że cały Kościół jest apostolski, że każdy wierny jest wiernym w komunii ze wszystkimi, i że pasterze sprawuja w tym apostolstwie szczególną funkcję, odpowiadającą ich misji i ich charyzmatowi w organicznej jedności Kościoła.

Stosunek wzajemności powinien ustalić się na wszystkich szczeblach życia eklezjalnego. Spontanicznie przychodzi myśl, że chrześcijanie, pełniący odpowiedzialne funkcje, winni żyć w trwałej więzi z bazq. Patrząc glębiej, chodzi o przejście od odpowiedzialności realizowanej w sposób nieco indywidualny do odpowiedzialności sprawowanej w komunii. Odpowiedzialność eklezjalna jest nie tylko wspólna, ale jest wspólnotowa. We wspólnocie chrześcijańskiej każdy

\footnotetext{
Św. Augustyn: Sermo 340, 1 (PL 38, 1483); por. K. Michalczak, dz. cyt., s. 46.

${ }^{6}$ Konstytucja dogmatyczna o Objawieniu Bożym Dei Verbum. W: Sobór Watykański II. Konstytucje, dekrety, deklaracje. Poznań 2002 s.354 n. 10,1.
} 
pozostaje zależny od wspólnoty eklezjalnej, której jest czlonkiem, której służy i wraz z innymi jest dla niej punktem odniesienia.

Idąc za koncepcją soborowa, należy zwrócić uwagę na fakt, iż Kościól jest budowany nie tylko przez akty urzędu hierarchicznego, ale przede wszystkim przez różnorodność służb i posług. Świeccy uczestniczą w diakonii przez te posługi.

Wszystko jest służbą. Kondycja chrześcijańska jest służbą - służbą samą w sobie dla służby światu, przez cały Kościól, dla zbawienia i spełnienia tegoż świata w Jezusie Chrystusie. Nie można więc - a nawet nie należy - przeciwstawiać sobie urzędów ustanowionych i charyzmatów. Urzędy zakładają i angażują charyzmaty: trzeba je jednak od siebie odróżniać.

W ramach natury życia chrześcijańskiego, która ma charakter fundamentalnie diakonalny, można ogólnie dostrzec typy posług wykorzystujących dary natury i łaski, które Bóg rozdziela i których pozwala używać dla wspólnego dobra. Wyraźnie tu mowa o posługach. Nie ulega jednak wątpliwości, że nie wszystkie one są równe treściowo i nie wszystkie się sytuują na jednej płaszczyźnie.

\section{Różnorodność posług w Kościele}

Yves Congar proponował po Soborze Watykańskim II wyróżnić trzy poziomy posług w misji Kościoła ${ }^{7}$.

Pierwszy poziom byłby poziomem służb raczej doraźnych, przejściowych, okazjonalnych. Filantropia i diakonia, których Bóg dokonał dla świata w Jezusie Chrystusie, wyrażają się i trwają dalej w służbach tworzących Kościół. Będzie więc mowa o "służbach", a nie o "posługach", choć oba słowa pochodzą od tego samego greckiego korzenia diakonia (diakon, sługa, minister). Często się jednak zdarza, iż dwa różne przekłady tego samego słowa wyrażają różne orientacje. Jeśli tłumaczyć diakonia jako służbę, chodzi wyłącznie o służbę; jeśli tłumaczyć to słowo jako posługe, jest ono rozumiane jako służba mająca pewną trwałość i jest już w jakiś sposób zatwierdzona.

Drugi poziom stanowią służby analogiczne, lecz bardziej trwałe $\mathrm{z}$ racji bardziej bezpośredniego zwiąku ze zwykłymi potrzebami i działaniami Kościoła. Te „posługi” są służbami wykraczajacymi poza to, co doraźne, okazjonalne. Sa to służby uznane lub poparte we wspólnocie i włączone w życie tej wspólnoty.

\footnotetext{
${ }^{7}$ Por. Y. Congar: Ministères et communion ecclésiale. Paris 1971 s.43-49.
} 
Mam tu na myśli stałych katechetów, lektorów czy odpowiedzialnych za służbę liturgiczna, nadzwyczajnych szafarzy Komunii św., prowadzącego chór, stałych pracowników Caritas oraz Akcji Katolickiej, itd. Niektóre z tych slużb mogą równie dobrze pochodzić z poziomu pierwszego, bardziej doraźnego i osobistego, jak z drugiego, bardziej stabilnego, lepiej zorganizowanego, wyraźniej uznanego publicznie. Wzbudza je Duch Święty, który udziela swych charyzmatów jak chce, dla wspólnego dobra.

Trzecim poziomem jest poziom posług związanych ze święceniami (ustanowionych), będących w pełni i w najmocniejszym znaczeniu urzędami publicznymi. One także wymagają powołania i dotyczą służby trwale obecnej w życiu wspólnoty chrześcijańskiej. Ponadto wymagają jednak ustanowienia czy konsekracji przez władzę, czyli ostatecznie - bezpośrednio lub pośrednio - przez episkopat; ustanowienia i konsekracji odpowiadających aktowi prawnemu i aktowi liturgicznemu. Ich podstawa ma więc charakter sakramentalny: diakonat, prezbiterat, episkopat. $W$ tych ramach istnieją różne stopnie, zgodnie $z$ jurysdykcją $i$ organizacją urzędów czy stanowisk. Prócz osobistych darów natury i laski, jakimi są charyzmaty, wkracza więc tutaj nowy element. Nie należy jednak rozdzielać nowego daru łaski, jakim jest sakrament święceń kapłańskich, od pierwszych darów, jakie go poprzedzaja, towarzyszą mu i go uzupełniają. Kościół wyświęca lub mianuje jednego ze swych czlonków, w którym wspólnota i władza uznaje takie dary, a wyświęceni czy mianowani szafarze starają się je rozwijać przez modlitwę i wierność swemu powolaniu. Nowy element kryje się tu w fakcie, iż jest to sakrament, czyli akt Boga odwołujący się do mesjanicznego dzieła Chrystusa. Nawet jeśli kapłaństwo urzędowe jest ustanowione w sytuacji funkcyjnej, i w ten sposób nie pochodzi z tego samego poziomu ontologicznego co chrzestbierzmowanie, to ma trwałość opartą na ontologii łaski. W stosunku do konstrukcji Kościoła i jego charakteru strukturalnego ma ono charakter znacznie bardziej wyrazisty niż wcześniej wymienione posługi.

\section{Posługi świeckich wiernych w Kościele}

Dopiero na tym tle można pełniej zrozumieć posługi, spełniane w życiu Kościoła przez świeckich wiernych. Podkreślić trzeba, że zwrot „w życiu Kościoła” nie oznacza tylko Kościoła, w którym sprawowana jest liturgia, ale także, a może przede wszystkim, Kościoła-komunii.

Apostolska odpowiedzialność świeckich opiera się na konsekracji chrzcielnej, pogłębionej i bardziej ukierunkowanej na życie społeczne przez konsekrację 
bierzmowania. Tak podejmowana odpowiedzialność apostolska za świat jest jednak czymś nieokreślonym.

Sobór Watykański II stwierdza, że przez chrzest zostajemy wlączeni w Chrystusa, co pociaga za sobą udzial w Jego trzech funkcjach: kaplana, proroka i króla. Sobór stanął jednak przed poważną trudnością sprecyzowania form apostolstwa świeckich. Formy te zmieniają się w zależności od kraju, np. dla Francuzów Akcja Katolicka jest rzeczywistością bardzo dobrze znaną, która wyjaśnia wszystko; dla Amerykanów zaś znaczy zupełnie coś innego, a często już nie kojarzy się z niczym. Sobór stwierdza więc, że misjq Kościoła jest nie tylko głoszenie i przekazywanie Jego (Chrystusa) laski ludziom, lecz także przepajanie i doskonalenie duchem ewangelicznym porzqdku rzeczy doczesnych. Swieccy zatem sprawujqcy te misję Kościoła pełniq swe apostolstwo zarówno w Kościele, jak i wświecie, tak w porzqdku duchowym, jak i doczesnym ${ }^{8}$.

Misja jest częścią powołania chrześcijańskiego. Jest zatem dana w samym wezwaniu, które tworzy Lud Boży. Świeccy nie mają kwalifikacji hierarchicznej, ale maja przede wszystkim swój byt chrześcijański i ontologiczny tytuł posłanych do świata. Chrystus i Duch Święty budują Kościól, pozwalając w różnoraki sposób uczestniczyć w nim wielkiej rzeszy ludzi. Nie ma zjednoczenia z Bogiem bez więzi z braćmi, dzielenia się z nimi i tworzenia braterskiej wspólnoty. Jezus Chrystus buduje swój Kościół wzywając i dając każdemu dary, którymi ów obdarowany, na miarę swych możliwości, powinien obdzielać wszystkich innych?

Koniecznym jest ukazanie komplementarności działań świeckich i duchownych. Istotnie, jeśli idzie o przedmiot, mamy do czynienia tylko z jedną misja, powierzoną całemu Kościołowi, zarówno wiernym jak i pasterzom, każdemu według tego, kim jest i jakie zajmuje miejsce. Ta komplementarność istnieje także w odniesieniu do jakości ludzkiej. Wynika to już z tego, co zostało powiedziane: jakość chrześcijańskiej aktywności świeckich wiąże się ze światem, w którym dokonuje się to działanie.

Posługi świeckich wiernych w życiu Kościoła podzielić można na trzy grupy: posługi w codziennym życiu, posługi w życiu publicznym Kościoła, a także, posługi w różnych funkcjach sprawowanych w Kościele i dla Kościoła.

\footnotetext{
${ }^{8}$ Dekret o apostolstwie świeckich Apostolicam actuositatem. W: Sobór Watykański II, dz. cyt., s. $381-382$ n. 5,1 .

${ }^{9}$ Por. D. Bourgeios: Duszpasterstwo Kościola. Poznań 2001 s. 175-281. Seria: AMATECA. Podręczniki Teologii Katolickiej. T. 11.
} 


\section{Posługa świeckich wiernych w codziennym życiu}

Sobór Watykański II mówi nie tylko o kaplaństwie urzędowym, ale także o duchowym kapłaństwie wiernych. Całe ich życie, życie małżeńskie i rodzinne, codzienna praca, wypoczynek ducha i ciała ${ }^{10}$, jeśli są spełniane w Duchu, stanowią materię duchowej ofiary chrześcijan.

Życie chrześcijanina trzeba widzieć jako duchową ofiarę. Słowo „ofiara” nie brzmi przyjemnie, gdyż kojarzy się od razu z trudnymi wyrzeczeniami. W rzeczywistości, ofiara polega na odnoszeniu się do boskości, na uciekaniu się do Boga. Całe życie może być w ten sposób duchową ofiara, gdy jest życiem ofiarowanym Bogu. Każdy z nas jest kapłanem tej duchowej ofiary. Nowy Testament bez wahania przyznaje wszystkim wiernym tytuł kapłaństwa: albo zbiorowe pojęcie hierateuma - kapłaństwo (w 1 Liście św. Piotra), albo w sposób jeszcze bardziej konkretny, wyraźny - tytuł kapłana (w Apokalipsie).

Przedmiot królewskiego kapłaństwa jest natury moralnej, gdyż dotyczy samego życia osoby. Chodzi o kapłaństwo duchowe, choć jeszcze trzeba ustalić, jak rozumiemy sens tego przymiotnika.

Królewskie kaplaństwo, o którym mówi Pismo św., Ojcowie i tradycja Kościoła, polega na składaniu w darze ofiar duchowych, które nie są niczym innym jak życie samego czlowieka. Nasze kapłaństwo duchowo-rzeczywiste, którego jesteśmy kapłanami z tytułu zaproszenia do świętości, jest realizowane i sprawowane w darze ze wszystkiego, co możemy uczynić, aby wejść w prawdziwa przyjaźń z Bogiem.

\section{Posługa świeckich wiernych w publicznym kulcie Kościoła}

Jak podkreśla św. Piotr, nasze kapłaństwo chrzcielne sprawujemy w celebracji liturgicznej: wy również, niby żywe kamienie, jesteście budowani jako duchowa świqtynia, by stanowić święte kapłaństwo, dla składania duchowych ofiar, przyjemnych Bogu przez Jezusa Chrystusa (...). Wy zaś jesteście wybranym plemieniem, królewskim kapłaństwem, narodem świętym, ludem [Bogu] na własność przeznaczonym, abyście ogłaszali dzieła potegi Tego, który was wezwał z ciemności do przedziwnego swojego światta (1 P 2, 5, 9). W celebracji jesteśmy zatem kapłanami na mocy naszego chrztu: oddajemy cześć Bogu, uświęcamy Jego imię. Jesteśmy świątynią, osobiście i zbiorowo.

\footnotetext{
${ }^{10}$ Konstytucja dogmatyczna o Kościele Lumen gentium. W: Sobór Watykański II, dz. cyt., s. 137 n. 34.
} 
Liturgia polega na publicznym kulcie. Jest miejscem, w którym Kościół realizuje się i wyraża w sposób najbardziej autentyczny. Liturgia jednoczy i harmonizuje osobiste życie wewnętrzne i akt wspólnotowy. Nie może być aktem samego tylko kapłana wobec asysty i audytorium, ale jest wspólnym aktem calego Kościoła.

Udział wiernych w ofierze eucharystycznej wiąże się nie tylko z ich jakością kapłańską, otrzymaną na chrzcie i bierzmowaniu, ale z faktem, iż trwając w jedności Kościoła, sq oni w Ciele Chrystusa, a ofiara z tego Ciała jest również ich ofiara. Kościół jest uważany za pierwszy i integralny podmiot ofiary eucharystycznej. Rola świeckich związana z Eucharystią sytuuje się więc na poziomie duchowym, na egzystencjalnym poziomie świętości. Zostało to wyrażone w formule, którą można spotkać już w XIII w.: wierni przez pragnienie, modlitwę i żarliwe zjednoczenie voto czynią to, co kapłani czynią przez funkcję i kompetencję ministerio ${ }^{11}$. W tej perspektywie chodzi nie o to, by wierni jednoczyli się duchowo z akcją liturgiczną sprawowaną tylko przez kaplanów hierarchicznych na mocy właściwej i osobiście posiadanej władzy kapłańskiej - ministerialnej, lecz o to, by swą wiarą i modlitwą przyczyniali się do rzeczywistej i skutecznej celebracji tej akcji liturgicznej. Nie jest ona bowiem dziełem samych kapłanów, ale dziełem całego Kościoła, bo tylko w jego jedności istnieje posługa kapłańska. Sprawowanie ofiary eucharystycznej należy do całego Kościoła. Wierni nie tylko składają przez swych kapłanów i razem z nimi ofiarę Boskiej ofiary, ale składają również ofiarę Kościoła. Tylko wyświęceni kapłani mają władzę dokonywać celebracji sakramentalnej, natomiast wszyscy wierni jednoczą się i współdziałają z tą celebracją ${ }^{12}$.

Kapłaństwo chrzcielne rozwija w pełni swą wartość liturgiczną w uczestnictwie w celebracjach Kościoła, a zwłaszcza w Eucharystii. Wszyscy ochrzczeni, z tytułu swego kapłaństwa chrzcielnego, mają uczestniczyć w kulcie czysto sakramentalnym, sprawując go nie jak hierarchiczny szafarz, ale lącząc się, przyjmując, jednocząc się z szafarzami.

${ }^{11}$ Por. Y. Congar: Jalons pour une theologie du laïcat. Paris 1953 s. 288.

${ }^{12}$ Por. tamże, s. $222,280-282,290$. Aby to zrozumieć, zdaniem Y. Congara, należy pokrótce przypomnieć kilka punktów teologii dotyczących mszy: 1) Chrystus złożył siebie w ofierze jeden raz; w tej ofierze zawarł ofiarę nas wszystkich. 2) Ofiara mszy św. jest w istocie i zasadniczo pamiątka. sakramentalną celebracją ofiary krzyża; odtwarza sakramentalnie i realizuje ofiarę Chrystusa w czasie i w przestrzeni, aż do chwili Jego powrotu. 3) Msza św. jest nie tylko ofiarą Chrystusa w znaczeniu ofiary złożonej przez samego Chrystusa. Jest również ofiarą Kościoła, i to na dwa sposoby: jako ofiara Chrystusa jest składana przez Kościól, a jako składana w niej własna ofiara Kościoła, jest składana w ofierze Chrystusa i przez ofiarę Chrystusa (por. Y. Congar: Jalons pour une theologie du laïcat, dz. cyt., s. 284-287). 
Mówiąc o posłudze wiernych świeckich w publicznym kulcie Kościoła trzeba także powiedzieć o możliwości udzielania sakramentów przez świeckich. Sakramentu małżeństwa udzielają sobie sami małżonkowie. Kaplan jest świadkiem urzędowym i blogosławi związek malżeński na mocy przyjętych święceń kapłańskich. Ten sakrament małżeństwa pokazuje, że nie są oni więc tylko otrzymującymi sakramenty święte. Drugim sakramentem, który mogą udzielać świeccy to sakrament chrztu świętego. Mowa jest tutaj o sytuacji, kiedy istnieje niebezpieczeństwo śmierci noworodka. Jeśli dziecko przeżyje, nie otrzymuje powtórnie sakramentu chrztu św. od kaplana, ponieważ raz ochrzczone, więcej tego sakramentu nie przyjmuje. Kapłan w imieniu Kościoła dopełnia tylko tego sakramentu, namaszczając krzyżmem, błogosławiąc dziecko i wpisując do księgi ochrzczonych $^{13}$.

Ktoś może powiedzieć, że w udzielaniu sakramentów, już na pierwszy rzut oka, widać znacznie mniejszy udział świeckich wiernych niż kapłanów. Nie chodzi jednak o dyskusję nad ilością, ale nad jakością. Każdy, kto podkreślałby ten problem, musi sobie uświadomić godność każdego we wspólnocie i zróżnicowanie charyzmatów oraz posług.

\section{Posługa świeckich wiernych w różnych funkcjach kościelnych}

Mówiąc o posługach świeckich wiernych nie można pominąc ich roli w nauczaniu $^{14}$. Mam na uwadze przede wszystkim katechezę szkolna, która w znacznym stopniu jest prowadzona przez świeckich katechetów. Napotykają oni $z$ pewnością na wiele trudności, wynikających głównie $\mathrm{z}$ zacierania się w społeczeństwie wartości autorytetu rodzica, nauczyciela, księdza. Wielu krytykuje katechezę szkolną nawet dzisiaj, trzynaście lat po jej wprowadzeniu do szkół. Jakkolwiek byśmy nie spojrzeli, powszechność katechezy jest ogromną szansa dla młodych ludzi. Nawet jeśli dzięki katechezie nie spotkają osobiście Jezusa Chrystusa, to jednak zostaja przygotowani do takiego spotkania. Podkreślić też trzeba, że polscy katecheci w większości sa dobrze przygotowani do swojej pracy. W wielu Kościołach lokalnych na Zachodzie, katechetami są oddani Kościołowi rodzice, rzadko jednak przygotowani teologicznie do pełnienia tej funkcji.

Nauczanie to nie tylko katecheza. Coraz więcej świeckich prowadzi zajęcia na wydziałach teologicznych wyższych uczelni. Przykładem są zwłaszcza uniwersyteckie wydziały teologiczne, gdzie stale rośnie liczba świeckich osób, zatrudnionych na stanowiskach dotąd zastrzeżonych wyłącznie dla kapłanów.

\footnotetext{
${ }^{13}$ Por. B. Glinkowski: Chrzest. Poznań 2001 s. 17-19. Seria: Prawo Kościoła na co dzień.

${ }^{14}$ Por. A. Faivre: Les laïcs aux origines de l'Église. Paris 1984 s. 72 -91.
} 
Nauczanie to także, uczestnictwo świeckich wiernych w działalności duszpasterstwa rodzin, gdzie od lat prowadzą poradnie rodzinne oraz przygotowanie młodych do małżeństwa.

W czasach, kiedy coraz więcej mówi się o potrzebie nowej ewangelizacji, istnieje konieczność zaangażowania się absolwentów wydziałów teologicznych w prowadzoną przez Kościół tzw. formację permanentną. Taka działalność musi się odbywać w stosunkowo małych grupach, dobrze zorganizowanych od strony strukturalnej, prowadzonych nie przez kapłanów, ale odpowiednio do tego przygotowanych i odpowiedzialnych świeckich. Kapłani bowiem nie są $w$ stanie objąć wszystkich obszarów aktywności wspólnoty.

Ogromną rolę mają do spełnienia świeccy wierni w przygotowaniu poszczególnych osób do przyjęcia sakramentów. Przygotowanie rodziców i chrzestnych przed chrztem dziecka można, przynajmniej w części, powierzyć świeckim. Coraz częściej słyszy się o świeckich, którzy pod kierownictwem kapłana przygotowuja mlodziez do sakramentu bierzmowania w małych, kilkuosobowych grupach. Ogromny teren do zagospodarowaniu stanowi opieka nad chorymi i starszymi w parafii, która winna być uwieńczona udzielaniem sakramentu chorych. Kapłani, bez pomocy świeckich, nie obejmą troską tak wielu osób, o których istnieniu często nawet nie wiedza.

Kolejnym miejscem, gdzie świeccy winni czynnie uczestniczyć w życiu kościelnej wspólnoty, to doradztwo w szerokim tego słowa znaczeniu. Podstawowym polem tego rodzaju aktywności sa parafialne rady duszpasterskie i ekonomiczne, istniejące $w$ niektórych parafiach już od dłuższego czasu. Sa parafie, gdzie one pięknie pomagają $\mathrm{w}$ budowaniu wspólnoty parafialnej, są też takie, gdzie potrzeba jeszcze wiele wysiłku, aby zaczęły one w pełni realizować swoje zadania.

Na koniec pragnąłbym podkreślić, że nie można mówić o kapłaństwie wszystkich ochrzczonych i o kapłaństwie ministerialnym bez ukazania Jezusa Chrystusa jako jedynego Kapłana. Jest On jedynym Kapłanem, ponieważ kapłaństwo nierozerwalnie związane jest $\mathrm{z}$ ofiara, a tylko On złożył jedyna, niepowtarzalną ofiarę. My wszyscy, tzn. duchowni i świeccy, uczestniczymy, każdy w sposób sobie właściwy, w jednej niepowtarzalnej ofierze Chrystusa przez chrzest i bierzmowanie. Sa różne stany w Kościele, z których wynikaja różne posługi. Tym, co nas łączy i co czyni odpowiedzialnymi w Kościele i za Kościót, jest 
chrzest św., wszczepienie w Chrystusa, który jest twórcą i głową Kościoła. Mieć udział w kapłaństwie - ministerialnym czy powszechnym - oznacza służyć!

Mimo, że upłynęło już blisko czterdzieści lat od zakończenia Soboru Watykańskiego II, trzeba ciągle wskazywać świeckim ich miejsce w Kościele i zachęcać do aktywnego uczestnictwa w życiu wspólnoty. Nie można jednak zapominać o różnicy między kapłaństwem wszystkich ochrzczonych a kapłaństwem ministerialnym a także o posłuszeństwie Ewangelii i Kościołowi. 
